\title{
PET-CT-MRI-Based Cardiovascular Imaging
}

Editors

POUL FLEMMING HØILUND-CARLSEN

ABASS ALAVI

MATEEN C. MOGHBEL

ALI SALAVATI

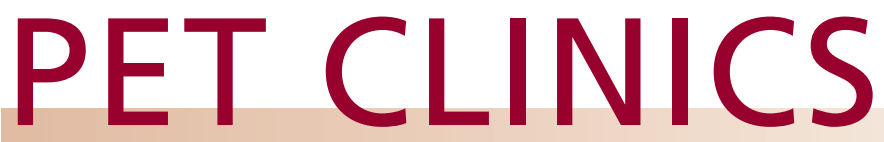

www.pet.theclinics.com

Consulting Editor

ABASS ALAVI

April 2019 • Volume 14 - Number 2 